\title{
KASIH KARUNIA YANG MULIA
}

Dalam bukunya “What's So Amazing About Grace?” Philip Yancey mengisahkan satu cerita dari meja diskusi di suatu konferensi perbandingan agama-agama. Apakah keistimewaan Kekritenan dibandingkan dengan agama-agama lain? Ada yang mengajukan perihal inkarnasi Kristus, tetapi dalam agama-agama lain juga punya pemahaman bagaimana Allah menampakkan diri dalam bentuk manusia. Kebangkitan? Dalam agama-agama lain ada juga kisah bagaimana orang kembali dari kematian. Ketika C.S. Lewis masuk ke pertemuan itu, dan bertanya topik apa yang sedang diperbincangkan? Pertanyaan itu diulangi lagi, apa keistimewaan agama Kristen dibandingkan agama-agama lain? C.S. Lewis segera menjawab bahwa itu mudah, yang istimewa dalam kekristenan adalah kasih karunia (grace).

Dalam Bahasa Indonesia grace dapat diterjemahkan sebagai rahmat, anugerah, atau kasih karunia. Kasih karunia adalah hal yang paling istimewa yang pernah timbul dalam pikiran manusia, yakni anugerah Allah yang tak bersyarat yang mengampuni orang berdosa dan mengaruniakannya keselamatan, hidup yang kekal tanpa bayaran (gratis) di dalam iman kepada Yesus Kristus. Dalam KBBI anugerah diartikan sebagai "pemberian atau ganjaran dari pihak atas (orang besar dan sebagainya) kepada pihak bawah (orang rendah dsb); karunia (dari Tuhan). Dalam terminologi Kristen kasih karunia atau anugerah adalah rahmat Tuhan dalam pengorbanan Kristus bagi keselamatan orang berdosa. Sola Gratia, semata-mata oleh anugerah.

\section{Kasih Karunia Yang Hampir Punah}

Dalam Oxford Learner's Dictionary, grace diartikan sebagai an attractive quality of movement that is smooth, elegant and controlled. Dalam Yohanes 1:14,16,17 dengan pengertian kontemporer Kristus telah datang dengan kepenuhan kasih karunia, yang dapat diartikan sebagai keanggunan kasih Kristus yang sangat menarik perhatian. Setiap kali di mana Dia berada dalam tiga puluh tiga setengah tahun Ia berjalan dalam rupa manusia di Palestina, orang-orang selalu datang berkumpul di sekeliling-Nya. Kalau diamati dari cara orang-orang itu berpakaian, bahasa dan prilaku mereka yang tanpa aturan, jelas mereka ini bukanlah dari golongan orang-orang beragama atau saleh pada umumnya. Mereka adalah orang-orangorang berdosa, para pemungut cukai, dan pelacur-pelacur. Mereka berasal dari latar belakang yang tidak baik, yang dianggap sebagai masyarakat kelas dua, golongan terpinggirkan, bahkan dianggap sebagai sampah masyarakat. Tetapi ketika mereka datang dekat kepada Tuhan, lihatlah wajah-wajah mereka berubah, penuh cahaya, mata mereka berbinar-binar dengan kesukaan pengharapan, ya mereka umat yang melihat keindahan anugerah Ilahi. Saat di hadirat-Nya mereka mendapatkan eksistensi dan harga dirinya yang telah terkoyak oleh rasa malu dan rasa bersalah.

Namun hal ini menjadi kontras dengan gambaran tentang gereja zaman ini. Gereja mengaku sebagai kumpulan dari pengikut-pengikut Kristus yang penuh kasih karunia. Realitanya gereja bukanlah tempat yang ramah dikunjungi oleh para pendosa dan kaum terpinggirkan. Rasanya aneh jika saat ini kita melihat ada gelandangan datang ke gereja dengan pakaiannya yang compang-camping, dengan model yang tidak "beragama". Sebelum mereka itu mencapai pintu gerbang gereja, bisa jadi sudah diusir. Atau jika mereka lolos dari penjagaan dan sukses masuk ke dalam gereja, maka mereka akan menjadi sasaran cemoohan dan pergunjingan. Jangan harap ada yang segera datang menghampiri dan memeluk cipika cipiki atau 
sekadar menegur sapa dan menyediakan tempat. Orang berdosa semakin terasing di tempat yang penuh anugerah (grace).

Hal ini telah dirasakan oleh seorang gembala sidang yang baru ditahbiskan pada suatu gereja yang besar dengan ribuan jemaat. Ia datang ke gereja itu dengan pakaian compang-camping layaknya seorang gelandangan. Ia datang lebih awal lalu berdiri di depan gereja yang akan dipimpinnya itu dan mencoba menyapa orang-orang, tetapi tidak ada yang menyahut dengan ramah. Dia bahkan tidak dianggap, kehadirannya tidak diacuhkan. Ia lalu masuk ke dalam gereja dan mencoba duduk di bagian depan, tetapi segera diusir oleh usher (penerima tamu) dan diminta duduk di belakang saja. Ia pun mencoba menyapa orang-orang, ada tiga orang saja yang menjawab. Tetapi tiba-tiba orang-orang menjadi terperangah ketika diaken gereja mengumumkan dan memperkenalkan gembala sidang yang baru, dan gelandangan itu yang maju ke depan. Ia pun mengambil microfon dan mulai berbicara bercerita bagaimana pengalamannya pagi itu, ia tertolak dan tiada yang memandangnya dengan mata anugerah, semua menghakimi dan mencemooh, padahal seharusnya sebagaimana firman Tuhan ajarkan jemaat harus menjadi seperti Kristus yang penuh kemurahan. Mendengar itu banyak jemaat yang tertunduk dengan rasa bersalah, ada yang menangis dan merasa malu. Sang gembala ini kemudian mencopot pakaian compang campingnya, tetapi benar tidak semudah itu untuk melepaskan rasa kaget dan kecewa dan heran dengan sikap orang-orang yang beragama. Ada apa dengan gereja masa kini? Di mana hati yang berbelaskasihan? Gereja telah jatuh dalam legalisme yang mati dan mematikan.

\section{Kasih Karunia dan Kebenaran}

Kasih karunia bukan berarti sikap kompromis terhadap dosa. Dalam dekade-dekade terakhir ini berkembang suatu pemahaman terhadap kasih karunia yang diistilahkan oleh Michael L.Brown sebagai hyper grace, yang oleh pencetus ajaran ini mereka sebut sebagai grace revolution atau double grace yang sangat mengedepankan anugerah dan anti terhadap legalisme. Ajaran ini menyatakan bahwa Allah begitu mengasihi manusia dan Ia sudah mengampuni segala dosa manusia, baik masa lalu, dosa masa kini bahkan dosa-dosa masa yang akan datang. Karena itu mereka menyebut tidak perlu lagi pengakuan dosa, bahkan tidak usah memusingkan dosa lagi. Dosa sudah diselesaikan sepenuhnya oleh Kristus di kayu salib. Hal yang kedengarannya luar biasa, berita yang segar dan membebaskan, tetapi sayang mereka ternyata mengabaikan tuntutan Tuhan, yakni kebenaran. Sebab mereka mengajarkan dosa yang diperbuat tidak perlu diakui, dan tidak lagi perlu dukacita karena pertobatan. Pantas ada yang menyebutkan bahwa gerakan ini sebagai promotor dari anugerah murahan (cheap grace) sebab mengkompromikan tuntutan kebenaran.

Ingatlah bahwa kebenaran tidak bertentangan dengan kasih karunia, di dalam Kristus keduanya berpadu menjadi satu "penuh kasih karunia dan kebenaran" (Yohanes 1:14), bukan "kasih karunia atau kebenaran". Injil adalah kebenaran yang disampaikan dalam cawan anugerah, di sinilah letak perbedaannya dengan Taurat (legalisme). Taurat itu adalah kebenaran juga (Rom 7:12) tetapi sebagai kebenaran yang disampaikan dalam cawan legalisme: hukum dan peraturan. Masalahnya mengapa Taurat menjadi mematikan adalah karena manusia itu sendiri sudah jatuh dalam dosa, sehingga alih-alih membawa kelepasan, Taurat justru membawa perhambaan. Peraturan membelenggu bukan membebaskan. Tetapi kebenaran dalam cawan anugerah adalah kebenaran yang memerdekakan (Yohanes 8:30-36). 
Pendekatan anugerah (Injil) itu lebih efektif dari pada pendekatan Taurat karena Injil menyelesaikan akar persoalan manusia, yakni dosa, sedangkan Taurat hanya sebatas menunjukkan apa itu dosa.

Kesalehan dan perbuatan baik manusia sebagai penawar keberdosaan manusia dipromosikan agamaagama, tetapi itu hanyalah kain compang camping bertambal sulam yang dikenakan oleh orang-orang beragama. Dosa itu memisahkan manusia dari Allah, dosa menelanjangi manusia di hadapan Allah. Hanya di dalam iman kepada Yesus Kristus sajalah manusia menerima pembenaran, pengudusan, diampuni dan dikuduskan untuk menjadi serupa segambar kembali dengan Khaliknya. Ya, memang masih dalam proses, tetapi terus-menerus dibaharui. Oleh anugerah orang berdosa diampuni, oleh anugerah kepalanya tegak pasti menatap masa depan sebab kemudian ada janji Imanuel, penyertaan Allah. Tak heran Matius menyebut bahwa nama-Nya adalah Yesus sebab Dialah yang akan mengampuni umat-Nya dari dosa mereka dan sekaligus Imanuel: Allah beserta kita (Matius 1:21, 23).

\section{Kasih Karunia-Nya Cukup Bagi kita}

Ada masa-masa krisis yang manusia hadapi, bahkan ketika kita hidup di dalam janji penyertaan Tuhan. Krisis itu diizinkan, entah dalam perjalanan nikah rumah tangga, keluarga atau bisnis, bahkan dalam pelayanan. Bisa juga dalam kehidupan pribadi. Krisis itu bisa singkat atau berkepanjangan hingga menggoreskan banyak cerita duka yang menjadi kabur tak terbaca karena buram oleh tetesan air mata. Paulus merasakan bagaimana ia mengalami 'tajamnya tusukan duri' di dalam dagingnya, dalam tubuhnya seizin Tuhan mengalami gocohan Iblis. Ini membuatnya lemah, sudah tiga kali ia berseru kepada Tuhan supaya ia dilepaskan. Tetapi bukan kelepasan yang ia terima, hanya kata-kata peneguhan namun berkuasa, "Cukuplah kasih karuniaku bagimu, sebab dalam kelemahanlah kuasaku menjadi sempurna."

Dalam Yoh 1:14-16 pribadi yang penuh anugerah itu bukanlah manusia biasa, sebab dikatakan Dia adalah Firman yang menjadi daging. Dan Yohanes 1:1-3 mengatakan bahwa Firman itu adalah Allah sendiri Dia yang patut kita sembah; Dia adalah Firman yang menciptakan segala yang ada yang tanpa Dia tidak ada yang telah jadi dari segala yang dijadikan; dan Firman itu adalah terang hidup dan kegelapan tidak berkuasa atas-Nya. Dia saja cukup bagi kita.

Ketika Allah mengampuni kita, memang kita menerimanya dengan gratis, tidak ada suatu usaha yang kita bayarkan untuk itu selain dengan percaya, iman. Sola fide. Tetapi sebenarnya hal itu gratis bukan karena anugerah itu tidak berharga, itu gratis sebab sudah ada yang menanggungnya, yakni Kristus sendiri. Dia membayarnya dengan tunai dan tuntas di kayu salib ketika Ia berseru: "te telestai", "sudah selesai". Namun tentu kasih karunia ini memiliki tujuan, kasih karunia diberikan supaya manusia kembali kepada jalan keselamatan menuju kemuliaan, untuk menjadi serupa dan segambar dengan Khaliknya. Dalam konteks inilah kemudian kebenaran mendapat tempatnya. Sebab sejak semula apa yang Allah mau dari Abraham dan keturunannya ialah supaya ia hidup dalam kebenaran dan keadilan dengan tidak bercacat di hadapan Allah (Kejadian 17:1; 18:19). Maksud dari kasih karunia ini adalah agar manusia itu menjadi kudus di dalam segenap hidupnya sama seperti Ia kudus adanya. Dan anugerah Tuhan cukup bagi orang percaya untuk ia hidup dalam kodrat Ilahi.

Sangat luar biasa. Tema kasih karunia ini pastinya melebihi tema mukzijat. Ketika mukzijat terjadi memang bisa menjadi moment yang spektakuler, namun jelas kesembuhan hanya berdampak pada tubuh fisik. Sementara moral manusia yang sudah rusak oleh dosa tidak tersentuh dengan mukzijat kesembuhan. Kehadiran anugerah dan belaskasih Kristus yang menyentuh hati manusialah yang membawa pertobatan 
dan pembaharuan bahkan pengudusan hidup. Sunngguh, kasih karunia ini adalah kasih karunia yang mulia.

Karena kuasa ilahi-Nya telah menganugerahkan kepada kita segala sesuatu yang berguna untuk hidup yang saleh oleh pengenalan kita akan Dia, yang telah memanggil kita dengan kuasa-Nya yang mulia dan ajaib. (2 Petrus 1:3).

\section{Penutup}

Kiranya kita jangan menyia-nyiakan anugerah sebesar ini, kiranya kita jangan mencemarkan anugerah yang teramat kudus dan mulia ini. Selamat Natal (Jannen R. Pangaribuan) 